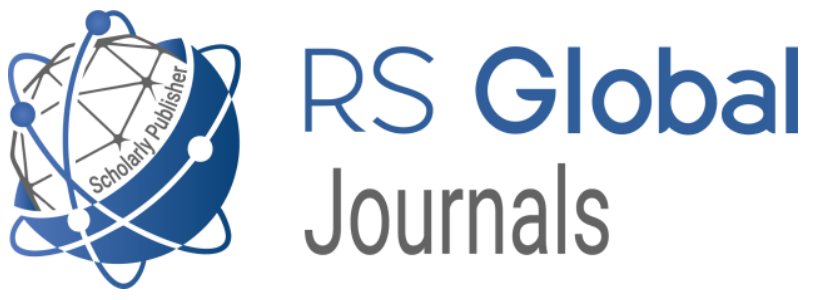

Scholarly Publisher

RS Global Sp. z O.O.

ISNI: 0000000484952390

Dolna 17, Warsaw, Poland 00-773

Tel: +48226022703

Email: editorial_office@rsglobal.pl

JOURNAL International Journal of Innovative Technologies in Social Science

p-ISSN 2544-9338

e-ISSN 2544-9435

PUBLISHER RS Global Sp. z O.O., Poland

ARTICLE TITLE PROSE OF I. NECHUI-LEVYTSKYI (THE CASE OF NOVEL "KNIAZ JEREMIAH VYSHNEVETSKYI")

AUTHOR(S) Vilna Yaroslava Volodymyrivna

Vilna Ya. V. (2020) The Issue of Denationalization in Historical Prose of I. Nechui-Levytskyi (the Case of Novel "Kniaz Jeremiah

ARTICLE INFO Vyshnevetskyi”). International Journal of Innovative Technologies in Social Science. 6(27). doi: 10.31435/rsglobal_ijitss/30092020/7154

DOI https://doi.org/10.31435/rsglobal_ijitss/30092020/7154

RECEIVED 16 July 2020

ACCEPTED 12 August 2020

PUBLISHED 18 August 2020

LICENSE

This work is licensed under a Creative Commons Attribution

4.0 International License.

(C) The author(s) 2020. This publication is an open access article. 


\title{
THE ISSUE OF DENATIONALIZATION IN HISTORICAL PROSE OF I. NECHUI-LEVYTSKYI (THE CASE OF NOVEL "KNIAZ JEREMIAH VYSHNEVETSKYI")
}

\author{
Vilna Yaroslava Volodymyrivna, \\ Doctor of Philology, Taras Shevchenko National University of Kyiv, Kyiv, Ukraine, \\ ORCID ID: https://orcid.org/0000-0002-1026-5198
}

DOI: https://doi.org/10.31435/rsglobal_ijitss/30092020/7154

\begin{abstract}
ARTICLE INFO
Received 16 July 2020

Accepted 12 August 2020

Published 18 August 2020

\section{KEYWORDS}

historical novel, figurative thinking, idea, problem of denationalization, national identity, inferiority complex.

ABSTRACT

The article considers the format of figurative thinking of the classic of Ukrainian realistic literature of the XIX century - I. Nechui-Levytskyi - in the field of historical prose. The novel "Kniaz Jeremiah Vyshnevetskyi”, which considers the problem of denationalization, is analysed. The peculiarities of the author's optics in tracking the formation of conformist features and later a renegade, in the descendant of the glorious Ukrainian family of Jeremiah Vyshnevetskyi are recorded. The author's opinion on the role of education, objective realities and individual psychology in the processes of formation and deformation of personality on the example of the protagonist of the work, the prototype of which was a real historical figure, is taken into account.
\end{abstract}

Citation: Vilna Ya. V. (2020) The Issue of Denationalization in Historical Prose of I. Nechui-Levytskyi (the Case of Novel "Kniaz Jeremiah Vyshnevetskyi"). International Journal of Innovative Technologies in Social Science. 6(27). doi: 10.31435/rsglobal_ijitss/30092020/7154

Copyright: (C) 2020 Vilna Ya. V. This is an open-access article distributed under the terms of the Creative Commons Attribution License (CC BY). The use, distribution or reproduction in other forums is permitted, provided the original author(s) or licensor are credited and that the original publication in this journal is cited, in accordance with accepted academic practice. No use, distribution or reproduction is permitted which does not comply with these terms.

Introduction. In the historical and literary context of Ukraine, the second half of the nineteenth century occupies a special place. It is at this time that literature acquires the characteristics by which we can define it as classical literature. Significant changes in the spheres of national culture, the formation of national self-awareness (from the initial ethnocentric impulse to nation-building pathos, nation-cultural development, philosophy of the Ukrainian national idea), depiction of the fullness of life of that time in difficult historical and social conditions formed those inalienable values that will determine the immanent features of Ukrainian literature for many decades in the future.

Creative works of I. Nechui-Levytskyi - one of the central prose writers of this period requires special attention and thoughtful commentary not only because Ukrainian realistic prose of this period is associated with his name but also because the basis of that association is a fairly approximate understanding of the specifics of Ukrainian realism and, moreover, of the iconic work of the writer. The stability of a number of stereotypes about the work of I. Nechui-Levytskyi is due to the fact that for decades a school curriculum remains comprises only the stories "Kaidasheva Simya" and "Mykola Jeria", which, incidentally, partly encourages the perception of Ukrainian classical literature of XIX century as a purely ethnological literature, understanding this definition as a sign of the predominance in it of themes and problems from the lives of ordinary people, mostly peasants.

Research results. I. Nechui-Levytskyi, as repeatedly was noted by literary critics (S. Yefremov, I. Franko, M. Wozniak, O. Biletskyi, M. Tarnavskyi et al.), primarily in the problemthematic and figurative ranges, was a bold and conscious innovator. 
Reflecting on the features of the Ukrainian character and dramatic events of national history, the writer could not help noticing that the same national types, on the features of which he thought so much, and which he wrote so succinctly and plastically in his works, are not composed today - they are only being modified in the current dimensions. So, the characters of the past can explain current issues a lot.

For the creative personality of the second half of the XIX century, which was formed not only on the concepts of positivism, but also on the ideas of romantic aesthetics, an appeal to history in general, to comprehend specific historical events of the Polish-Cossack confrontation was expected. As well as few Ukrainian prose writers of this time (who also knew European and American historical fiction well), he could not miss the opportunities open after lifting of bans on the printing of historical works as well as works from the life of the intelligentsia.

The writer also realized that the appeal to the historical theme in Ukrainian fiction should have ideological motives, and he understood that in the literary space of that time it was strange for him personally to even think about a purely fictional historical work. Times were not for fun. And the experience of the reader's persistent fascination with the national ideals of the main characters (Shrama, Cherevania, Somka) from P. Kulish's "Chorna Rada" was also the best confirmation that the text of such a genre in Ukraine can only be Ukrainian-centric.

However, gaining popularity for work that has the potential of only a relevant ideology is always extremely problematic, because what is meant as the success of the author, is subject to the presentation to the public of ideas that are implemented in the text of high quality. Thus, the writer's responsibility for the effectiveness of the creative search in work of a similar subject and genre is multiplied.

It is noticeable that I. Nechui-Levytskyi took into account the writing experience of P. Kulish and to a lesser extent focused on the experience of the Polish writer Senkevych and the Ukrainian writer M. Starytskyi. In addition, his opinion of Senkevych's historical works was generally critical. This is evidenced by the writer's letter to N. Kobrynska dated July 5, 1900. According to his confession, "I could not finish reading Senkevych's "Polanetskyi" (the Polonetskyi family) and finished bypassing pages, not to mention his "Flood" and "Pan Volodiyevskyi" that can be read only by Polish patriots, - it's all dry and non-life" [2, 365]. I. Nechui-Levytskyi considered these creative works as deliberately complementary to figures in Polish history, as local patriots, who were really going through another difficult period, needed such examples to raise national spirit and, ultimately, consolidate forces opposing Russian ones.

It is also self-evident that the author's position of I. Nechui-Levytskyi in historical works also had its own specifics. It consisted in offering readers his own author's optics in view on the past. This was expressed in several segments. The first concerned the choice of historical personalities. The fact is that in historical essays and works of art the writer turned to "... figures who sought their own answers to the deep questions of national identity in different periods of Ukrainian history" [4, 271]. Thus, the writer gave everyone the opportunity to find answers to the questions that are periodically updated, and in Ukrainian history (actually, as in Polish) dominate almost continuously, namely: the origins of the "people's spirit", the problem of correlation of individual and national interests, mission of a leader in the national movement and in general socio-political life; consequences for the spiritual and political life of denationalization processes. Finally, he called for an understanding of the level of responsibility not only of the extraordinary individual, but also of literally everyone for living their own lives with dignity, and thus, perhaps, for the lives of their generation.

I. Nechui-Levytskyi, as an artist and scientist, was able to find answers to these questions in ways that are not given to everyone. He worked extensively in the archives, wrote several historical popular science essays ("The First Kniazi of Kiev", "Ukrainian Hetman Bohdan Khmelnytsky and the Cossacks", etc.). He was acquainted with and used the concepts of historical works of M. Kostomarov, V. Antonovych, O. Levitskyi, O. Lazarevskyi et al., the chronicles of the seventeenth and eighteenth centuries, and, as a result, quite expectedly turned to the artistic understanding of Ukrainian history. We mean the works "Hetman Ivan Vyhovskyi", "Kniaz Jeremiah Vyshnevetskyi".

The above-mentioned author's optics had a second segment, the meaning of which precisely referred to how the art work should reveal the life tactics and strategy of historical characters. By the way, the psychology of the character can be revealed mainly through actions and deeds or through internal monologues. Mixing these methods (long-tried in the literature) - which also best express the characterology - the writer still sought to comply with the standards of historical fiction of the time, for example: he portrayed the format of opposition pairs of heroes-antipodes (Jeremiah Vyshnevetsky 
- Todozia; Vyshnevetskyi - people), i.e. used the same principle that has already sounded good in "Clouds" and "Over the Black Sea".

However, it is interesting that the writer could deviate from the absolute of this principle, as he had done in his previous historical work - the novel "Ivan Vyhovskyi", where the intertwining of two story lines (the story of the family of Ivan Vyhovskyi and the family of an ordinar cossack Demko Liutay) is not takes on all the reader's attention, because no less attractive to readers are bright, ambiguous, and sometimes contradictory other characters: Bohdan Khmelnytskyi, Yuri Nemyrych, Yuri Khmelnytskyi, Olesia Vyhovska, Anna Zolotarenko, Hetman's sister Kateryna, and others.

Thus, in the historical and biographical work "Kniaz Jeremiah Vyshnevetskyi" (1897) the writer referred to the events of the seventeenth century but gave an assessment not only of the wellknown dramatic protest events directed by Ukrainians against the pressure of aristocratic Poland, but personalized these protests with diverse historical figures.

The writer, on the example of the life story of Jeremiah Vyshnevetskyi, known from historical, folklore and literary sources, gives readers a reason to think about why Ukrainian history developed in the past in this but not in another way. Observe what the hero, who is considered a werewolf in Ukraine, should feel. Finally, to analyse what prompted him to betray the glorious family and the interests of the Motherland, thus satisfying his own ambition and realizing the thirst for power. Or did he have different personal motivations that played a role in his life choices or other objective factors that his descendants could not fully imagine? For the writer these questions seemed to be important still the first versions of the title of the story were already marked by his evaluative prescription: "Werewolf" or "Apostate". But the author's consciousness is not like a mathematical matrix, which should be perceived as an absolute. Therefore, only from a first glance it seems that I. NechuiLevytskyi in the interpretation of this historical character follows only a sharply negative assessment of the figure of the kniaz in Ukrainian folklore and in the works of such historians as M. Kostomarov and O. Lazarevskyi. But is it only in the convincing exposure of the traitor of the Ukrainian people that the reason for the failed five attempts to publish the text of the story during the author's lifetime lies? Some of the conflicts of that time can be understood from the writer's letters, in particular, to Ivan Balei in February 1902.

Problems with the plans to print the work "Kniaz Jeremiah Vyshnevetskyi" began after the devastating response to this manuscript by the Polish historian Korzon, whose opinion had to be taken into account by editors, especially in Galicia. I. Nechui-Levytskyi treated the causes and consequences of this situation quite calmly and even ironically but not so much as to abandon the idea of publishing the novel: "The editorial board of 'Kyivska Staryna' did not want to publish my story because of Korzon and told me to publish it not even under my own name, bearing in mind that Polish critics would tarnish my name, although ... I don't think it has anything to do with it because Jeremiah was not a Pole, but a pure Ukrainian; he only, having found his ideal in Poland and the privileges of the Polish nobility, became a werewolf and broke away from the democratic Ukraine of that time and shed Ukrainian blood, probably as much as the Cossacks shed Polish in Polonne and in Bar. But I don't care when all sorts of blows fall on my shoulders. And which of the Poles will read the story?" [2, 395396]. The writer, as a man with many years of experience in Poland, understood perfectly well that Poles would always support a favourable version of events of that time.

I. Nechui-Levytskyi created not just a historical novel but specifically preferred the historical and biographical subspecies of this genre, because in this format he planned to give and, in fact, fully realized his vision of the defining stages in the development of Jeremiah's character, depicting his dynamic life from young to mature years.

It is interesting to trace how the final figurative conception of the author was formed, which Polish historians and critics disagreed with. It is worth saying that back in 1878, in the article "Contemporary Literary Direction" I. Nechui-Levytskyi noted that a literary work must be a national work (in addition - both folk and realistic). Therefore, when he wrote in that work that: "The principle of nationality consists of two features: the outer, upper - the national language, and the central - the deeply national mental character of the people. The peoples` language is the body of nationality, the national mental character is its soul" $[3,15],-$ therefore he was not only appealing to the national feeling of contemporaries, but thus contributed to their own vision of the mechanisms of influencing the consciousness and soul of readers who must understand the actions of the hero because they are described in the native language, and because, thanks to the author's skill, they are able to imagine and 
feel the problems of the inner world of the hero, literally feeling the beating of his pulse as his own. The result is that the character of Jeremiah Vyshnevetskyi is specially described in constant dynamics, important changes and the subtle nuances of his inner states.

At first he appears as a bright, passionate and a little dreamy young man, in the face of which one can read "fierceness and zeal": "And the young kniaz now thought that he, leaving his parents' house, as if set sail from the shore, set off on that spacious blue boundless sea to seek happy destiny and great glory, such glory that it overshadowed the glory of all kniazes, hetmans, and kings, blinded the whole world ... that rumours about his name and his glory spread from end to end and resounded with songs. How songs about the glorious Cossack deeds of the glorious knight Yarema BaidaVyshnevetskyi was sound" [1,8] (literary critics have clarified this error of the writer regarding the name of the hero's ancestor - it is clear that it is about Dmytro Vyshnevetskyi).

In the course of the plot, the author gives readers the opportunity to understand how "selfish and ambitious" he became, how ruthless he can be in relations with people. He appears as a cruel executioner in adulthood, receiving literally "satanic joy", watching his fellow tribesmen be brutally tortured, who, according to the Polish authorities, are not just spontaneous rebels, but dangerous enemies, because they are fighters for freedom and independence of the Ukrainian people. In this case, we are talking about minor characters in the work: the old Cossack, Orthodox priests, burghers.

In order not to make this striking change in the character seem artificial, I. Nechui-Levytskyi describes Yarema's family situation at the beginning of the work. After the death of his father and mother, the guardian of the boy became his uncle Constantine, who "long ago converted to Catholicism and Polish ideology" [1, 6], although the rudiments of national identity in his mentality are still sometimes felt.

Uncle takes Jeremiah to the college of Jesuit fathers, who will gladly see to it that this representative of the glorious and rich family becomes the enemy of Ukraine. There Jeremiah is taught: "Now you, kniaz, convert your people in Ukraine to a new faith, to a new homeland, to the Polish language. You are now a model for petty Ukrainian gentlemen, for the dark peasantry and bourgeoisie in Ukraine but they are not a model for you. You, Ukrainian gentlemen who have converted to the Catholic faith ... Follow in the footsteps of those dark comrades, "that cattle", process them even by force, and they, like the blind, must follow you, their leaders. And when they do not go behind you, you have a sword in your hands. Arm your sword in the name of Christ" $[1,17]$.

The writer notes that the whole atmosphere of the college from the beginning to the end of the training provoked the young man to doubt himself: "Like tempting demons, the Jesuits whispered as if by accident hatred to Jeremiah's faith, to his language, and the young proud kniaz, as soon as he left the college, joined the Catholic faith, abandoned the Ukrainian language and became Polish ideologist" $[1,17]$. The author also emphasizes the features of Jeremiah's nature that led him to choose this alien field of life.

Obviously, in the hardly self-conscious deep internal complexes lie the reasons for his desire, even passionate need, to dominate over others, especially the Polish magnates. The fact of how early the complex of superiority was manifested in him (which, from the point of view of certain schools of psychology, is the reverse side of the inferiority complex) is also an important factor for I. NechuiLevytskyi in his experience of creation of a figurative system. The writer emphasizes that the complex is manifested directly or indirectly, but always stable in relation to both enemies and relatives. Moreover, even before studying at the Jesuit college, he was: "Proud and unkind to his elders and higher in status, Jeremiah was friendly to his servants. He even fraternized and united with the noble servants but in the same fraternization there was a kind of secret ridicule, covered with jokes and laughter" [1,7].

As he gets a little older, he always thinks about how to be not only equal but also to surpass his ancestors. Thus, readers are presented with a personality that is internally unstable, dissonant, which is fundamentally different from the image that he presents to the outside.

Jeremiah's cruelty in adulthood to all without exception is not hidden: "...We will dance on the blood of Cossacks and peasants" [ibid., p. 85]; fear of losing the opponent (at least the story of marriage to Griselda); his persistent desire to be first in everything: "He grabbed the land, grabbed the property wherever it was possible to grab. He collected money and created a bifurcated force of the court army to become the highest of all magnates and to rule over the lords of all Poland, Lithuania and Ukraine" [ibid., p. 95]. All these are manifestations not only of strength and determination, but 
also of those internal problems that were the result of the destruction of spiritual safeguards, previously stabilized by the forces of the Orthodox faith, the axiological principle of native culture, the ideas of freedom and the desire for independence, the power of honour and not yet humiliated dignity. To some extent, its cruelty is a protective mechanism based on the psychological need for hyper compensation. Therefore, "...he did not care whether he was Ukrainian or Polish: faith was a formality for him, without which it is impossible to achieve a high goal set for him" [ibid., 38].

The real historical character Jeremiah Vyshnevetskyi, according to many historians, had positive traits: he was raised a brave warrior, later became a good proprietor and, at the same time, an experienced and authoritative military leader. But the protagonist of "Kniaz Jeremiah Vyshnevetskyi" demonstrates subjectivity not only on the battlefield, he marries the daughter of a Polish nobleman Griselda, proving his own rationalism, which can also be interpreted as one of the protective mechanisms of a destabilized personality.

From all these personal "chess strategical moves" of Jeremiah, it is noticeable that the dominant motivation for him is always the subconscious need for self-realization in a very specific way: self-affirmation through manipulation of others. This is not just his snobbery or unfounded contempt for people. It is about the need to implement compensatory functions, about the manifestations of reactions to insults in the young years, when he, as a representative, at the discretion of the Poles, an inferior ethnic group, although veiled but still tried to humiliate. The episode, which is again connected with the enrolment of Jeremiah in the college, can be illustrative here, when its leaders staged a brilliantly performed play in front of the young man, emphasizing the high educational level of their institution, their own altruism in the field and friendship with a new student. But the clever Jeremiah feels how he is literally scanned by church leaders to understand the future benefits and the price for them: "This kniaz brought us a frown and a wolfish son but the countless estates of the Vyshnevetskyi... This young kniaz is not a very inclined tree ... but the power of money... Oh, if only we could attract this beast to our camp, so that sometimes it wouldn't bother us later. God forbid, if he sometimes follows Kryshtof Kosynsky and Nalyvayko!" [1, 14]. The apotheosis of this well-thought-out action is a joint prayer for the young prince: "But it was not about Jeremiah's mind, not about goodness and truth, with accompaniment sound of the organ. But the prayer was like the prayer of evil spirits that the kniaz became the enemy of his native land and shed the river of native blood ... "[1, 16], - the author notes.

In fact, I. Nechui-Levytskyi in the main events of this work captures the manifestation, according to A. Adler, the features of a typical inferiority complex in Jeremiah, a complex of both personal and ethnic. Thus, author does not justify the existential choice of the kniaz but only seeks to be objective in assessing his personality. Other local circumstances and objective historical events would hardly reveal to the reader the image of an exemplary warrior, a true Cossack, etc., as the writer also properly illustrates Jeremiah's constant and, by its nature, compensatory desire for impenetrable complacence.

This can be illustrated by the love story of Jeremiah and Todozia. In parallel with the marriage of a Polish noblewoman, the story of his rapprochement with the widow of a registered Cossack develops. He is supposedly capable of passionate love for beauty, but it turns out that in this relationship his ego dominates, because he tends to banally "...enjoys the female beauty not seriously..." $[1,126]$ and is willing to easily leave a woman for the sake of "glory in battles, for selfishness and ambition" [ibid., p. 193].

The depiction of the circumstances and genetic traits under which Jeremiah was formed, whom his countrymen hated rather than loved, and whom the Poles, despite condemning his cruelty, still supported, became one of the main artistic tasks in this work for the writer. Thus, I. Nechui-Levytskyi, describing the life of Jeremiah Vyshnevetskyi, gave another example of the consequences of notfreedom, which became, in his opinion, a fait accompli for many members of the Ukrainian upper class several centuries ago. Therefore, it is not surprising that the protagonist at a certain stage of his life is already quite sure that: "We need to turn Ukraine into Poland. It is not for us, the kniazes, to follow the cattle blindly, but for them to be reworked in our way... We, gentlemen, must be for them both a selfgovernment and a kind of government, as has already happened in Poland" [ibid., pp. 72-73].

According to the author`s point of view, those who stop defending their national rights, who gladly or unwillingly, consciously or unconsciously (the essence is the same) are denationalized, forgetting "whose parents children are" - is the Cain seal of the entire Ukrainian people, because of 
the weakness the spirit and meanness of specific individuals will be paid not only by their direct descendants, but also by future generations as a whole. Such an ideological guideline of the work lies, so to speak, on the surface.

I. Nechui-Levytskyi, in contrast to O. Storozhenko, M. Starytskyi, and others, who portrayed Jeremiah as an already formed personality, sought to reach the very beginnings. Hence the writer's elucidation of the essence and causes, first of his conformism and then of open betrayal, hence the logic of fixing the manifestations of his immorality. Thus, the author portrays a hero of a certain psychotype, not a national stereotype.

The writer also finds convincing arguments for the complexity of personal choice at the time, which confirms his vision of the consequences of the process of destruction of national identity on the example of Jeremiah Vyshnevetskyi, and thus derived personality problems in the modern dimension of writer`s current life. I. Nechui-Levytskyi as an artist reflected on these problems in the late 60s of the XIX century in the story "Prychepa", and then continued the artistic development of the problem of the consequences of denationalization in the comedy "Na Kozhumyakakh" and in the satirical parody "Bez Puttia", and in the leading motifs of many other works.

Conclusions. As it was already noted, historical prose became one of the most productive genres of Ukrainian literature only at the end of the XIX century. The writer did a lot to make this genre one of the most popular. And the fact that the historical works of I. Nechui-Levytskyi have long remained on the margins of attention of critics, literary critics and readers of Central Ukraine since the end of the nineteenth century, and in the USSR almost all of the twentieth century. "Hetman Ivan Vyhovskyi" was first published in Galicia (1899), "Kniaz Jeremiah Vyshnevetskyi" in Kharkiv (1932) just shows that the writer quite convincingly extrapolated the past to the present, and, as we can understand now - for the future.

Therefore, it only seems that the author is an outside observer who seeks to take a balanced position in assessing the actions of his hero, interpreting him exclusively as a typical antihero. First of all, we must take into account that the idea of I. Nechui-Levytskyi's work is based on the global problem of denationalization for Ukrainians, and for the writer personally. This problem is not abstract, it is always personalized in any national history, even if over time the names of those who, in the opinion of the national community, made a wrong step are lost. The experience of those whose names have been preserved by human memory is even more noteworthy. But, in the author's opinion, only the analysis of the problem through the prism of individual psychology, through immersion in the world of the "inner man" gives a chance for success to such artistic analysis.

If we pay attention to the peculiarities of the poetics of the work, it has a well-thought-out composition, detailed conflict, proportionality of the main components. In this text a significant role is played by the spatio-temporal components of the plot organization: there are global battle scenes and scenes of confrontation of heroes (for example, Jeremiah Vyshnevetskyi and Maxim Kryvonos, etc.), actions of the nobility in the struggle for power, domestic scenes, retrospections, prophecies dreams, memoirs, inserted dumas, legends, letters, historical documents (direct and indirect citations of the 'Litopys Samovydcia', orders, universals, contracts, lawsuits, diaries).

The observed author's achievements in the implementation of the leading idea of the work "Kniaz Jeremiah Vyshnevetskyi", which is to condemn denationalization, allow us to talk not only about the relevance of the problems in the work of I. Nechui-Levytskyi, but also to record a natural increase in readers' attention to the story in last decades.

\section{REFERENCES}

1. Nechui-Levytskyi I. Povne zibrannia tvoriv u desiaty tomakh. Vol. 7. Kyiv, 1966. $294-358$ p.

2. Nechui-Levytskyi I. Povne zibrannia tvoriv u desiaty tomakh. Vol. 10. Kyiv, 1968. 587 p.

3. Nechui-Levytskyi I. Siohochasne literaturne priamuvannia abo nepotribnist velykoruskoi literatury dlia Ukrainy I dlia Slovianshchyny. Pavlohrad, 2010. 68 p.

4. Tarnavskyi M. Nechuvanyi Nechui. Kyiv, 2018, 287 p. 